\title{
A STUDY ON EFFICIENCY OF DISTRIBUTION NETWORK OF HATSUN PRODUCTS
}

\author{
Gowtham Aashirwad Kumar \\ Assistant Professor, Department of Management Studies, \\ BIHER - Bharath Institute of Higher Education and Research, Tamilnadu, India \\ Dr A Ravikumar \\ Associate Professor, Department of Tourism and Hospitality Management, \\ BIHER - Bharath Institute of Higher Education and Research, Tamilnadu, India
}

\begin{abstract}
A distribution channel implies the chain of business or middle people through which a merchandise or administration goes until arrives at the top customer. Accomplishment of every organization lies on different angles, among these the top customer.
\end{abstract}

Key words: Circular Shift Invariant, Translation Invariant, Visual Evoked Potential, Ensemble Averaging, Discrete Wavelet Transform (DWT), and SNR.

Cite this Article: Gowtham Aashirwad Kumar and Dr A Ravikumar, A Study on Efficiency of Distribution Network of Hatsun Products. International Journal of Electrical Engineering and Technology, 11(5), 2020, pp. 108-112.

http://iaeme.com/Home/issue/IJEET?Volume $=11 \&$ Issue $=5$

\section{INTRODUCTION}

Achievement of every organization lies on different viewpoints, among these the conveyance channel is that the most vital one. Circulation channel may be a chain of middle people: each passing the item down the chain to the subsequent association, before eventually arrives at the customer or end - client. This procedure is understood because the "appropriation chain" or the channel". all of the components in these chains will have their own dispersion channel for his or her item showcasing.

\section{REVIEW OF LITERATURE}

(Rosenbloom and Larsen, 2008), Nowadays, promoting channels which give the institutional structure that associates firms to the business sectors they serve have not gotten away from the worldwide condition. Despite what might be expected, in this day and age, showcasing channel structure and system must be detailed with regards to globalization. Hence, directors liable for creating and dealing with the appropriation channels that make items and 
administrations accessible to truly billions of clients around the globe face a more perplexing test than the past age of channel chiefs.

When all is said in done, the idea of appropriation alludes to where and how item and administrations are to be offered available to be purchased, all basic component and calculated backings for the exchange of products and enterprises just as responsibility for and administrations to the clients (Stern et al, 2006). An effective showcasing channel guarantees that an ideal item is appropriated in an ideal add up to an ideal channel to fulfill the ideal purchaser.

(Rosenbloom, 2010) states that Not just do the present channel chiefs need to think all inclusive, however they should likewise act locally regarding giving the suitable cluster of channels wanted by heterogeneous markets everywhere throughout the world.

Examination committed to channel the executives has assumed a significant job in the promoting discipline for more than 40 years. Two principle zones of directs research in advertising have developed. To start with, how channels are composed or organized has been a point of convergence, fixating fair and square of channel joining, dependence on numerous channels, appropriation power and hierarchical approaches identifying with centralization, formalization, normalization, and reconnaissance (cf. Dwyer and Oh, 1988; John and Weitz, 1988; Fein and Anderson, 1997; Shervani, Frazier and Challagalla, 2007).

\section{OBJECTIVES OF STUDY}

\section{Primary Objective}

To study about the effectiveness of distribution channel in Hatsun Products.

\section{Secondary Objectives}

- To find out the strength and weakness of distribution channel.

- To study about various problems faced by middle perople.

- To learn about the strategies for channel distribbution.

\section{RESEARCH METHODOLOGY}

Research Methodology is utilized to verifiable how research is done experimentally.

\section{RESEARCH DESIGN}

The research design used for the examination is descriptive research design.

\section{SAMPLE SIZE}

The sample size taken for study is 100 .

\section{POPULATION SIZE}

The population size is infinity.

\section{NEED FOR STUDY}

It mirrors the image of viability of appropriation channel and adequacy of focuses on fulfillment of dissemination mediators and quality and shortcoming of channel. Appropriation channel assumes a significant job in Footware industry.

\section{SCOPE FOR STUDY}

It examines about different organization exercises and its circulation procedure. 


\section{SAMPLING TECHNIQUES}

The sampling method taken for study is Convinient Sampling Method.

\section{LIMITATIONS OF STUDY}

As the technique for information assortment was mostly Questionnaire and Interview strategies. A few respondents may not releaved the genuine data and a few times on account of the predisposition. The quantity of merchant, distributer, retailers and clients cooperated were constrained. The data has been introduced in the wake of gathering information from Chennai Market as it were.

\section{DATA COLLECTION}

\section{Primary Data}

The primary data is the first hand data and it was collected through Questionnaire Method.

\section{Secondary Data}

Secondary data is collected through Journals, Magazines, Websites, etc.,

\section{DATA ANALYSIS AND INTERPRETATION}

Table 1 Purpose Behind The Selection Of Hatsun Products

\begin{tabular}{|c|l|c|c|}
\hline S.NO & \multicolumn{1}{|c|}{ PARTICULARS } & RESPONDENTS & PERCENTAGE \\
\hline 1 & Famous Brand Name & 30 & $30 \%$ \\
\hline 2 & Cheaper Products & 60 & $60 \%$ \\
\hline 3 & High Demand in Market & 05 & $05 \%$ \\
\hline 4 & Effective Selling & 05 & $05 \%$ \\
\hline & Total & 100 & $100 \%$ \\
\hline
\end{tabular}

\section{Inference}

Most of the respondents said that cheaper products is the reason behind the selection of hatsun products. $30 \%$ of respondents said that the cheaper products is the reason behind the selection of hatsun products. And $05 \%$ of respondents said both high demand and effective selling.

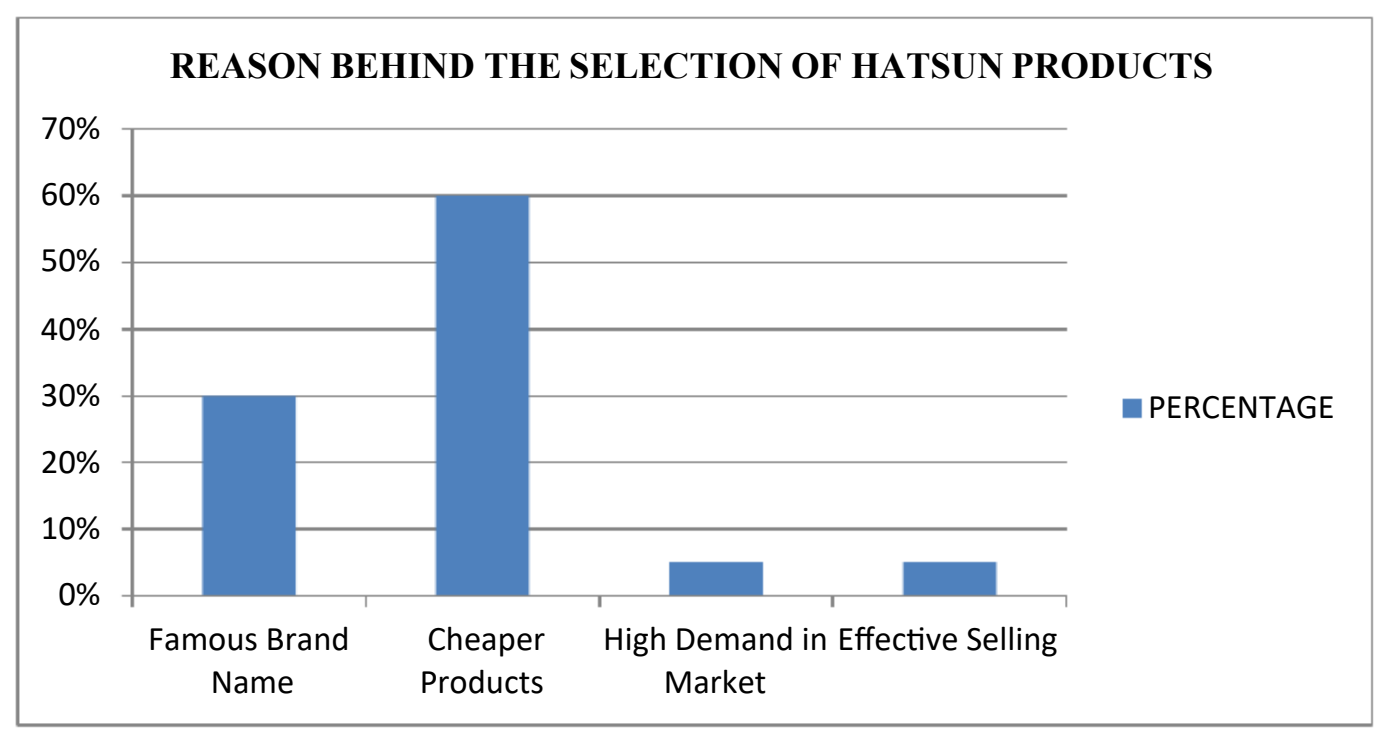

Figure 1 Reason Behind the Selection of Hatsun Products 
A Study on Efficiency of Distribution Network of Hatsun Products

Table 2 Good Level of Distributor Commission Rate for Hatsun Products

\begin{tabular}{|c|l|c|c|}
\hline S.NO & \multicolumn{1}{|c|}{ PARTICULARS } & RESPONDENTS & PERCENTAGE \\
\hline 1 & Satisfied & 80 & $80 \%$ \\
\hline 2 & Unsatisfied & 20 & $20 \%$ \\
\hline & Total & 100 & $100 \%$ \\
\hline
\end{tabular}

\section{Inference}

Most of the respondents were satisfied about the satisfactory level of distributor commission rate for hatusn products and only $20 \%$ of respondents were unsatisfied.

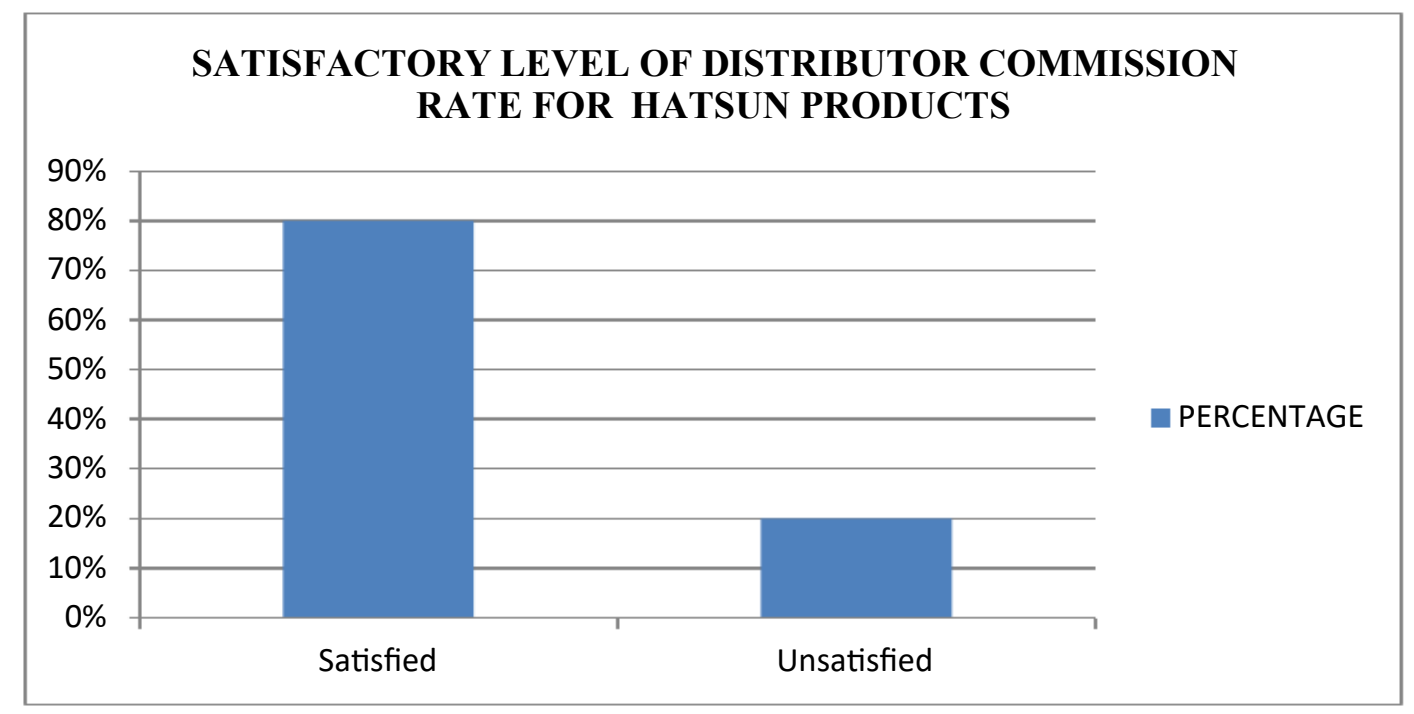

Figure 2 Satisfactory Level of Distributor Commission Rate for Hatsun Products

\section{Chi - Square Test}

Table 3 Chi Square Test for Explanation Behind the Selection of Hatsun Products

\begin{tabular}{|c|c|}
\hline 30 & 60 \\
\hline 05 & 05 \\
\hline
\end{tabular}

\section{Null Hypothesis}

There is no significant difference behind the reason of selection of hatsun products.

\section{Alternative Hypothesis}

There is the significant difference behind the reason of selection of hatsun products.

Table 4

\begin{tabular}{|c|c|c|c|c|}
\hline $\mathbf{O}$ & $\mathbf{E}$ & $\mathbf{( O - E )}$ & $(\mathbf{O}-\mathbf{E})^{\mathbf{2}}$ & $(\mathbf{O}-\mathbf{E})^{2} / \mathbf{E}$ \\
\hline 30 & 10.5 & 19.5 & 9 & 0.8571 \\
\hline 60 & 58.5 & 1.5 & 57 & 0.9743 \\
\hline 05 & 3.5 & 1.5 & 2 & 0.5714 \\
\hline 05 & 58.5 & -53.5 & 2862.25 & 48.927 \\
\hline & & & Total & 49.9013 \\
\hline
\end{tabular}


Chi - Square Test $=(\mathrm{O}-\mathrm{E})^{2} / \mathrm{E}$

Chi - Square Test $=49.9013$

Degrees of Freedom:

$\mathrm{V}=[\mathrm{r}-1][\mathrm{c}-1]$

$\mathrm{V}=[2-1][2-1]$

$\mathrm{V}=1$

Table Value [T.V] $=3.84$

Calculated Value $[\mathrm{T} . \mathrm{V}]=49.9013$

Therefore C.V $>$ T.V

\section{FINDINGS}

- Most of the respondents said that less expensive items is the explanation for the choice of hatsun items.

- Most of the respondents were fulfilled about the acceptable degree of merchant commission rate for hatusn items.

\section{SUGGESTIONS}

- Increase the administration parlors and working for govt. worker.

- Dairy items should focused on sales rep visit for wide promoting.

\section{CONCLUSION}

From this study it is presumed that the greater part of the respondents said that less expensive items is the purpose for the choice of hatsun items and the majority of the respondents were fulfilled about the palatable degree of wholesaler commission rate for hatsun items.

\section{REFERENCES}

[1] Anderson, E., \& Coughlan, A. (2002). A channel management: structure, governance and relationship management. In B. Weitz, \& R. Wensley, Handbook of Marketing (pp. 224-247). London: Sage Publications.

[2] Brent, M. (2007). Channel Structure and Strategic Choice in Distribution Channels. Journal of Management Research, Volume 7, Number 2.

[3] Coughlin, A., Anderson, E., Stern, L., \& El-Ansary, A. (2001). Marketing Channels. Upper Sadlle River, NJ: Prentice-Hall.

[4] Dwyer, R. F., \& Welsh, M. A. (1985). Environmental Relationships of the Internal Political Economy of Marketing Channels. Journal of Marketin Research , 397-414.

[5] Frazier, G. L. (1999). Organizing and Managing Channels of Distribution. Journal of the Academy of Marketing Science, 27, No. 2, 226-240. 